\title{
PENYUSUNAN DAN PENGUJIAN METRIK OPERABILITAS UNTUK SISTEM INFORMASI AKADEMIK BERDASARKAN ISO 25010
}

\author{
Dwi Lesmideyarti ${ }^{1}$, Siti Rochimah ${ }^{2}$, Umi Laili Yuhana ${ }^{3}$ \\ Universitas Borneo Tarakan ${ }^{1 .,}$ Institut Teknologi Sepuluh Nopember ${ }^{2.3}$ \\ Email: $\underline{\text { dwilesmideyarti1@gmail.com }}{ }^{1}, \underline{\text { siti@its-sby.edu }^{2}}$, yuhana@its-sby.edu ${ }^{3}$
}

\begin{abstract}
ABSTRAK
Pesatnya perkembangan teknologi informasi dapat menjadi suatu keunggulan bagi organisasi untuk meningkatkan daya saingnya, tak terkecuali pada institusi pendidikan di tingkat perguruan tinggi.Kebutuhan teknologi informasi di perguruan tinggi sangat besar, terutama berkaitan dengan akademik.Sistem informasi akademik yang terkomputerisasi merupakan bagian penting di suatu perguruan tinggi. Hal ini dikarenakan dengan adanya sistem tersebut akan memudahkan dosen dalam memasukkan nilai akademik mahasiswa. Mahasiswa dapat mengakses informasi akademik atau kegiatan administrasi akademik.Sistem informasi akademik, sebagaimana sebuah sistem informasi pada umumnya, memerlukan adanya evaluasi untuk dapat mengetahui kekurangan-kekurangan yang ada untuk selanjutnya ditingkatkan dan dikembangkan.Oleh karena itu dibutuhkan metrik untuk mengukur kualitas dan mengevaluasi sistem informasi akademik.Penelitian ini melakukan penyusunan dan pengujian metrik operabilitas untuk sistem informasi akademik berdasarkan ISO 25010. Hasil yang didapatkan dari penelitian ini dapat menjadi masukan yang memperkaya kajian literatur dan empiris terkait pengukuran kualitas perangkat lunak menggunakan ISO/IEC 25010 karakteristik operabilitas.Data yang dibutuhkan untuk melakukan penyusunan dan pengujian metrik operabilitas untuk sistem informasi akademik berdasarkan ISO 25010 diperoleh dari studi liteatur, wawancara serta penyebaran kuesioner kepada responden pakar, dosen dan mahasiswa.Hasil dari penelitian ini dapat digunakan untuk mengevaluasi sistem informasi akademik berdasarkan ISO 25010 karakteristik operabilitas. Dari hasil penelitian, maka didapatkan hasil bahwa model yang diusulkan lebih akurat dibandingkan model lama, karena adanya penambahan dua subkarakteristik pada ISO 25010 karakteristik operabilitas yaitu helpfullness dan technical accessibility, yang mampu menaikkan akurasi model baru. Hasil pengukuran dari penelitian ini sudah memenuhi standar pengukuran kualitas. Standar kualitas untuk suatu aplikasi web adalah 70 .
\end{abstract}

Kata kunci: Sistem Informasi Akademik, ISO 25010, Metode Analythical Hyrarchy Process $(A H P)$

\begin{abstract}
The rapid development of information technology can be an advantage for the organization to improve its competitiveness, including in educational institutions at the college level. The Information technology needs in higher education is huge, especially with regard to the academic. Academic information systems are computerized an important part in a college. This is because the presence of such a system would facilitate faculty in incorporating
\end{abstract}


students' academic grades. Students can access information academic or administrative activities academic. Academic information system, as well as an information system in general, require an evaluation to be able to know the deficiencies that exist for further improved and developed. It is therefore necessary metrics to measure and to evaluate the quality of academic information systems. This research conducts a forming and testing of operability metrics for academic information system based on ISO 25010. The results obtained from this study can be input to enrich the literature and empirical studies related to measurement of software quality using ISO / IEC 25010 on operability characteristics. The data required to undertake the preparation and testing of operability metrics for academic information system based on ISO 25010 is obtained from literature studies, interviews and distributing questionnaires to the expert respondents, lecturers and students. The results of this study can be used to evaluate the academic information system based on ISO 25010 on operability characteristics. The research showed that the proposed model is more accurate than the old model, due to the addition of two sub-characteristic on operability characteristics of ISO 25010 that is helpfulness and technical accessibility, which is able to raise the accuracy of the new model. The measurement results of this study meet the standards of quality measurement. Quality standards for a web application is 70 .

Keywords:Academic Information System, ISO 25010, Analythical Hyrarchy Process (AHP) Method

\section{Pendahuluan}

Perkembangan teknologi yang semakin pesat mendorong semakin efisien dan efektifnya berbagai kegiatan yang dilakukan oleh manusia.Teknologi memungkinkan manusia melakukan pekerjaan dengan lebih cepat dan mudah, sehingga dapat mencapai tujuan dan target yang diinginkan.Di antara berbagai jenis teknologi yang mengalami kemajuan dan perkembangan tersebut, teknologi dalam bidang komputer dan informasi menjadi salah satu bidang yang dianggap memberikan sumbangan besar atas perubahan dari metode-metode konvensional yang ditempuh manusia menjadi metode terkomputerisasi. Wujud penerapan teknologi informasi dalam lingkup akademik adalah berupa Sistem informasi akademik, yang dirancang untuk memudahkan pengelolaan dan penggunaan data-data akademis untuk kepentingan institusi maupun pihak-pihak yang terlibat dalam lingkungan akademik, Sistem informasi akademik, sebagimana sebuah sistem informasi pada umumnya, memerlukan adanya evaluasi untuk dapat mengetahui kekurangan-kekurangan yang ada untuk selanjutnya ditingkatkan dan dikembangkan. Evaluasi terhadap sebuah sistem informasi, dalam hal ini adalah Sistem informasi akademik, merupakan evaluasi yang dilakukan dengan menggunakan pengukuran pada aspek kualitas dari sistem informasi dengan mengacu pada standar pengukuran yang diakui oleh dunia internasional, antara lain model McCall, Boehm, FURPS, Dromey, ISO 9126, dan ISO 25010. Berdasarkan penjelasan yang telah dipaparkan, maka masalah yang diangkat adalah: "Bagaimana penyusunan dan pengukuran metrik operabilitas untuk Sistem informasi akademik pada modul FRS online berdasarkan ISO/IEC 25010 karakteristik operabilitas, maka tujuan yang hendak 
dicapai dari pelaksanaan penelitian ini adalah untuk menyusun dan menguji metrik operabilitas untuk pengukuran kualitas Sistem informasi akademik pada modul FRS online berdasarkan karakteristik ISO/IEC 25010 karakteristik operabilitas. Diharapkan hasil yang didapatkan dari penelitian ini dapat menjadi masukan yang memperkaya kajian literatur dan empiris terkait pengukuran kualitas perangkat lunak menggunakan ISO/IEC 25010.Secara lebih spesifik, diharapkan dapat terbentuk sebuah metrik pengukuran atas kualitas Sistem Informasi yang dapat diterapkan secara umum berdasarkan ISO/IEC 25010karakteristik operabilitas.

\section{Kajian Pustaka}

\subsection{ISO/IEC 25010}

Konteks dari penelitian ini adalah untuk melakukan evaluasi atas Sistem informasi akademik menggunakan standar kualitas International Standardization for Organization and International Electrotechnical Commission (ISO/IEC) 25010.Konsep dasar ISO/IEC 25010 dapat dilihat pada gambar 2.1.

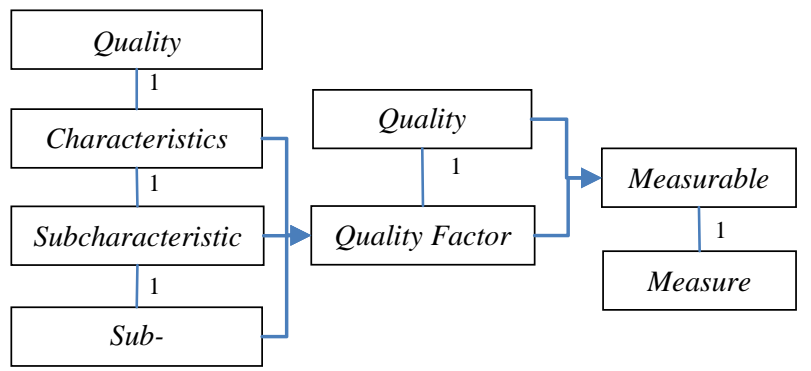

Gambar 2.1 Meta-Model Dari ISO/IEC 25010 (Wagner, 2013:61)

Secara keseluruhan, ISO/IEC 25010 memiliki delapan karakteristik untuk mengukur kualitas perangkat lunak secara menyeluruh, antara lain functional suitability, reliability, performance efficiency, operability, security, compatibility, maintainability, dan portability (Azuma, 2008:14).

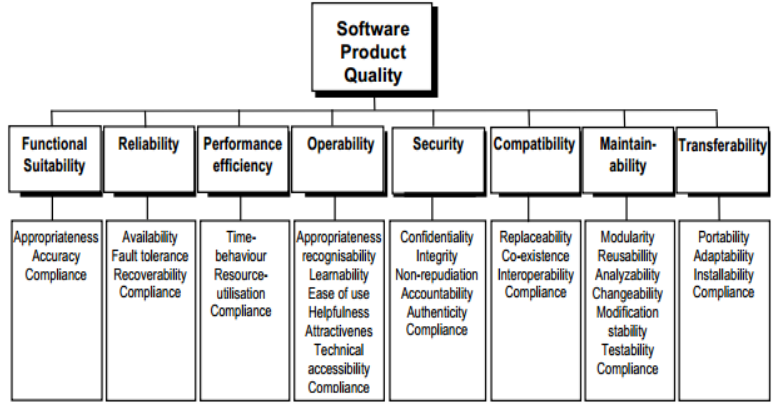

Gambar 2.2 Product Quality Model of ISO/IEC 25010 (Wagner, 2013:62)

\subsection{Kuesioner}

Kuesioner merupakan daftar pertanyaan yang akan digunakan oleh periset untuk memperoleh data dari sumbernya secara langsung melalui proseskomunikasi atau dengan mengajukan pertanyaan.

\subsection{Skala Likert}

Skala Likert menurut Djaali (2008) adalah skala yang dapat dipergunakan untuk mengukur sikap, pendapat, dan persepsi seseorang atau sekelompok orang tentang suatu gejala atau fenomena pendidikan. Skala Likert adalah suatu skala psikometrik yang umum digunakan dalam kuesioner, dan merupakan skala yang paling banyak digunakan dalam riset berupa survei.

2.3.Pengujian Validitas Dan Reliabilitas

\section{Instrumen}

Validitas adalah suatu ukuran yang menunjukan tingkat kevalidan atau kesahihan suatu instrumen. Prinsif validitas adalah pengukuran atau pengamatan yang berarti prinsif keandalan instrumen dalam mengumpulkan data.Metode untuk melakukan uji validitas adalah Korelasi Pearson Product Moment (r).

Tabel 2.1 Validitas Kuisioner Azwar, 2000 (Faizin, 2014)

\begin{tabular}{|l|l|l|}
\hline Koefisien Relasi & $R$ Kritis & Keterangan \\
\hline $\mathrm{r}$ hitung $<\mathrm{r}$ kritis & 0,4522 & Tidak Valid \\
\hline $\mathrm{r}$ hitung $\geq \mathrm{r}$ kritis & 0,4522 & Valid \\
\hline $\begin{array}{l}\text { Reliabilitas } \\
\text { pengukuran }\end{array}$ & yanstrumen adalah hasil \\
pengat dipercaya.
\end{tabular}


Reliabilitas instrumen diperlukan untuk mendapatkan data sesuai dengan tujuan pengukuran. Uji reliabilitas pada penelitian ini menggunakan metode alpha Cronbach.

Tabel 2.2 Reliabilitas Kuesioner

\begin{tabular}{|l|l|l|}
\hline Koefisien Reliabilitas & A Kritis & Keterangan \\
\hline $\mathrm{a}<\mathrm{a}$ kritis & 0,60 & Tidak Reliabilitas \\
\hline $\mathrm{a} \geq \mathrm{a}$ kritis & 0,60 & Reliabilitas \\
\hline
\end{tabular}

2.4.Metode Analythical Hirarchy Process (AHP)

Penilaian atau pembobotan subkarakteristik dan internal atribut digunakan untuk melihat pengaruh strategis terhadap sasaran, yang dinilai melalui perbandingan

berpasangan.Langkah-langkah

pembobotan menggunakan metode AHP adalah sebagai berikut :

Membuat matriks perbandingan

berpasangan antar subkarakteristik dan matriks berpasangan antar internal atribut.

Tabel 2.3 Penilaian Kriteria Berdasarkan

Skala Perbandingan Saaty

\begin{tabular}{|l|l|}
\hline \multicolumn{1}{|c|}{ Nilai } & \multicolumn{1}{|c|}{ Keterangan } \\
\hline 1 & A sama penting dengan B \\
\hline 3 & A sedikit lebih penting dari B \\
\hline 5 & A jelas lebih penting dari B \\
\hline 7 & A sangat jelas lebih penting dari B \\
\hline 9 & Mutlak A lebih penting dari B \\
\hline $\begin{array}{l}2,4,6, \\
8\end{array}$ & Apabila ragu-ragu antara dua nilai yang berdekatan \\
\hline
\end{tabular}

Penentuan prioritas digunakan dengan menggunakan teknik perbandingan berpasangan(pairwise comparisons) untuk atribut.

Tabel 2.4 Input Awal Bobot

Subkarakteristik Operabilitas

\begin{tabular}{|c|c|c|c|c|c|c|}
\hline & $\mathrm{K}_{1}$ & $\mathrm{~K}_{2}$ & $\mathrm{~K}_{3}$ & $\mathrm{~K}_{4}$ & $\mathrm{~K}_{5}$ & $\mathrm{~K}_{\mathrm{n}}$ \\
\hline $\mathrm{K}_{1}$ & 1 & & & & & \\
\hline $\mathrm{K}_{2}$ & & 1 & & & & \\
\hline $\mathrm{K}_{3}$ & & & 1 & & & \\
\hline $\mathrm{K}_{4}$ & & & & 1 & & \\
\hline $\mathrm{K}_{5}$ & & & & & 1 & \\
\hline $\mathrm{K}_{\mathrm{n}}$ & & & & & & 1 \\
\hline Jumlah & & & & & & \\
\hline
\end{tabular}

Nilai masing-masing kolom (A) ditentukan dengan menggunakan formula berikut:
$A(i, j)=n$, sehingga $A(j, i)=\frac{1}{n}, j i k a ~ i \neq j$

$A(i, j)=A(j, i)=1$, jika $\mathrm{i}=$

Di mana:

$\mathrm{i}=$ baris

$\mathrm{j}=$ kolom

Tahap berikutnya adalah melakukan normalisasi matriks, yaitu dengan mempertimbangkan setiap nilai kolom $\mathrm{j}$ dalam matriks $\mathrm{A}$, dengan menggunakanpersamaan 3 .

$\sum_{\mathrm{i}} \mathrm{a}_{\mathrm{ij}}=1$

Dimana: $a_{\mathrm{ij}}$ adalah elemen matriks A

Tahap selanjutnya adalah menghitung bobot atau eigen factor setiap atribut, yang dilakukan dengan menggunakan formula berikut:

$\mathrm{WI}=\frac{1}{n} \sum_{\mathrm{j}} \mathrm{a}_{\mathrm{ij}}$

2.5.Melakukan Uji Rasio Konsistensi

Semua elemen dikelompokkan secara logis dan diperingkatkan secara konsisten sesuai dengan kriteria yang logis. Konsistensi penilaian ini dilakukan dengan cara perhitungan $\mathrm{CR}$ (consistency ratio). Dengan ketentuan bahwa, jika pembobotan memiliki nilai CR lebih kecil dari 0,100 maka pembobotan faktor kualitas tersebut konsisten; dan jika tidak maka dianggap tidak konsisten, sehingga penilaian harus diulang.

Adapun, formula yang digunakan untuk menghitung nilai indeks konsistensi adalah sebagai berikut:

$\mathrm{CR}=\frac{\mathrm{CI}}{\mathrm{RI}}$

Dimana:

$\mathrm{CR}=$ Consistency Ratio

$\mathrm{CI}=$ Consistency Index (Rasio penyimpangan/deviasi konsistensi)

$\mathrm{CI}=\frac{(\lambda \max -n)}{n-1}$

Dimana:

$\lambda \max =$ Nilai eigen terbesar dalam matriks berordo $n$

$\mathrm{n}=$ Jumlah ordo dalam matriks

$\mathrm{RI}=$ Random Index, yaitu indeks random yang dikeluarkan oleh Oaks 
Ridge National Laboratory yang dikembangkan oleh Wharton School Dapat dilihat pada tabel 2.5.

Tabel 2.5 Nilai Random Indeks

\begin{tabular}{|c|c|c|c|c|c|c|c|c|c|c|c|c|}
\hline N & 1 & 2 & 3 & 4 & 5 & 6 & 7 & 8 & 9 & 10 & 11 & 12 \\
\hline RI & 0,0 & 0,0 & 0,58 & 0,90 & 1,12 & 1,24 & 1,32 & 1,41 & 1,45 & 1,49 & 1,51 & 1,48 \\
& 0 & 0 & & & & & & & & & & \\
\hline
\end{tabular}

Selain menggunakan consistency ratio, uji konsistensi juga dilakukan dengan menggunakan indeks kappa.Rumus yang digunakan untuk menghitung indeks kappa adalah sebagai berikut:

$\mathrm{K}=\frac{\mathrm{P}_{\mathrm{a}}-\mathrm{P}_{\mathrm{e}}}{1-\mathrm{P}_{\mathrm{e}}}$

Dimana

$\mathrm{P}_{\mathrm{a}}$ adalah proporsi berapa perater yang setuju dengan hasil pengujian.

$\mathrm{P}_{\mathrm{e}}$ adalah proporsi perater yang tidak setuju dengan hasil pengujian.

Nilai indeks Kappa berkisar antara angka 0 sampai dengan 1, dengan interpretasi menurut Landis dan Koch (dalam Murti, 2011) sebagai berikut:

a. Jika nilai $\mathrm{K} \leq 0,40$, maka dapat diartikan bahwa kekuatan kesepakatan adalah buruk.

b. Jika nilai $\mathrm{K}$ berkisar di antara 0,41 sampai $\leq 0,75$, maka dapat diartikan bahwa kekuatan kesepakatan adalah sedang.

c. Jika nilai $\mathrm{K}$ berkisar di antara 0,76 sampai 1,00 maka dapat diartikan bahwa kekuatan kesepakatan adalah baik.

Jika hasil rasio konsistensi dan indeks kappa ternyata telah memenuhi syarat, maka tahap berikutnya adalah menyusun kuesioner.

\subsection{UJI COBA}

Uji coba dilakukan dengan menggunakan data set berupa data kuesioner untuk menilai kualitas sistem informasi di dua perguruan tinggi yaitu di Institut Teknologi Sepuluh Nopember Surabaya dan di Universitas Borneo Tarakan. Kuesioner berisi pernyataan-pernyataan yang akan digunakan untuk mendapatkan nilai masing-masing subkarakteristik. Peneliti menyebarkan 40 kuesioner kepada dosen dan mahasiswa ( 30 mahasiswa dan 10 dosen) untuk tiap perguruan tinggi. Uji coba dibahas pada bab 4. Data kuesioner diolah dengan rumus8 (Membrate, 2010) kemudian dimasukkan dalam model kualiatas lama, model kualitas baru dan model kualitas baru berbobot, selanjutnya dihitung bobot absolut dengan cara mengalikan bobot subkarakteristik dengan bobot relatif internal atribut subkarakteristik menggunakan rumus 9 (Sugiyanto, 2015). Selanjutnya nilai absolut dihitung dengan mengalikan nilai absolut dengan nilai internal atribut subkarakteristik menggunakan rumus 9 (Sugiyanto, 2015). Rata-rata kualitas responden dapat dihitung dengan menjumlahkan nilai absolut internal atribut subkarakteristik ke 10 sampai dengan nilai absolut internal atribut subkarakteristik ke 26 menggunakan rumus 11(Sugiyanto, 2015).

$\mathrm{Q}=\sum_{i=1}^{n} X i / n$

Dimana :

$\mathrm{Xi}=$ Total skor kuesioner / jumlah item kuesioner

$\mathrm{n}=$ Jumlah responden

Bobot Absolut (BA) = Bobot Subkarakteristik x Bobot Relatif

Nilai Absolut $(\mathrm{NA})=\mathrm{BA} \times$ Nilai Internal Atribut

Rata-rata kualitas SIA $=\mathrm{NA} 1+\mathrm{NA} 2+$ $\mathrm{NA} 3+\ldots .+\mathrm{NA} 26$

Perbedaan rata-rata kualitas SIA untuk setiap responden didapat dengan menghitung selisih nilai terbesar dengan nilai terkecil untuk masing-masing ratarata kualitas SIA menggunakan rumus 12(Sugiyanto, 2015). Rata-rata perbedaan dihitung dengan membagi total perbedaan nilai dengan jumlah kuesioner menggunakan rumus13(Sugiyanto, 2015 ). Perbedaan $=$ MAX (TKD,TKMhs) MIN(TKD,TKMhs)

Rata-rata perbedaan $=$

Total perbedaan $/ 26$ 
3. METODE PENELITIAN

\subsection{RANCANGAN DAN TAHAPAN PENELITIAN}

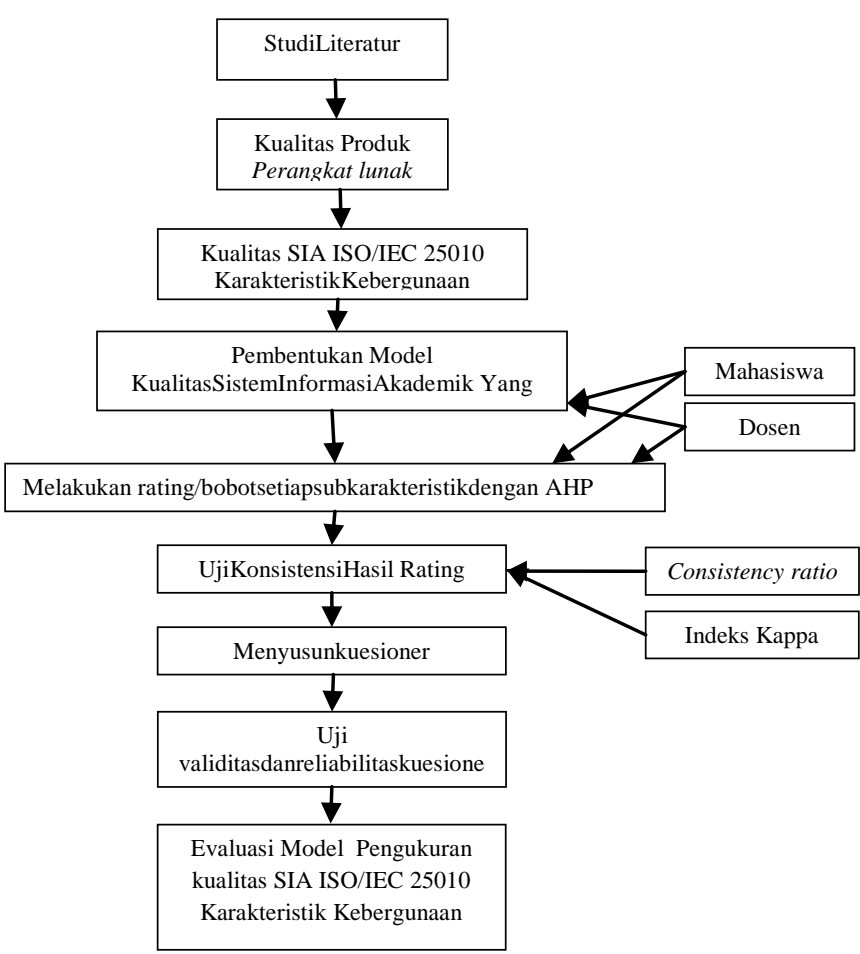

Gambar 3.1 Rancangan Penelitian

\subsection{Studi Literatur}

Pada tahap ini peneliti mencari berbagai referensi tentang teori kualitasperangkat lunak dan teori model kualitas perangkat lunak yaitu ISO 9126 dan ISO 25010.Selanjutnya, penulis mempelajari dan membandingkan standar ISO 9126 subkarakteristik kebergunaan dan ISO 25010 subkarakteristik operabilitas.

\subsection{Menentukan Kualitas Produk Perangkat Lunak}

Pada tahap ini peneliti melakukan penentuan kualitas produk perangkat lunak yang diamati dalam penelitian ini adalah program sistem informasi akademik yang akan diterapkan di ITS Surabaya dan Universitas Borneo Tarakan yaitu FRS Online yang terdiri atas lima modul, yaitu modul perwalian, modul entry nilai, modul transkrip, modul nilai, dan modul pengambilan mata kuliah.

Adapun, kriteria kualitas produk yang diamati didasarkan pada karakteristik kualitas produk perangkat lunak yang ditetapkan berdasarkan ISO/IEC 25010.

3.4. Pembentukan Model Kualitas Sistem Informasi Akademik Yang baru

Penelitian ini menggunakan 5 langkah pembentukan model kualitas yang pernah diusulkan oleh Al-Safadi dan Gracia (2012) antara lain :

1. Mempelajari model kualitas yang sudah ada dan memilih salah satu model kualitas yang akan digunakan sebagai basis acuan.

2. Mengidentifikasi subkarakteristik dan internal atribut pada sudut pandang dosen dan mahasiswa yang dapat ditambahkan pada model kualitas tersebut.

3. Memilih kelompok yang akan memberi nilai pada masing-masing subkarakteristik dan internal atribut yang ada

4. Memilih pakar yang familiar dengan sistem informasi akademik untuk menilai bobot dari setiap subkarakteristik dan internal atribut dari sudut pandang dosen dan mahasiswa

5. Membentuk model kualitas yang baru. Hasil dari mengidentifikasi subkarakteristik dan internal atribut (langkah 2), dan penilaian bobot dari subkarakteristik dan internal atribut (langkah 4) akan membentuk karakteristik baru.

3.5.Melakukan Pembobotan dengan Menggunakan Analythical Hierarchy Process (AHP)

Pemberian nilai bobot untuk masingmasing subkarakteristik dan internal atribut menggunakan metode Analytical Hierarchy Process (AHP).

Metode pembobotan AHP digunakan dalam penelitian ini dengan alasan antara lain :

a. Model kualitas menggunakan subkarakteristik dan internal atribut yang bersifat multi kriteria. 
b. Untuk memperoleh bobot subkarakteristik dan bobot internal atribut yang bersifat hirarki.

c. AHP menyediakan fasilitas pengecekan konsistensi bobot yang disebut rasio konsistensi dan rasio penyimpangan (indeks konsistensi).

Kuesioner pakardiisi oleh pakar yang ahli dalam bidang manajemen kualitas perangkat lunak.

3.6. Penyusunan Kuesioner

Kuesioner ini dibuat berdasarkan Checklist Internal Atribut Subkarakteristik Operabilitas dan definisi dari masingmasing subkarakteristik operabilitas.

\section{HASIL DAN PEMBAHASAN}

4.1. UJI COBA KUESIONER

Uji coba kuesioner dilakukan untuk membuktikan apakah pengukuran kualitas produk Sistem informasi akademik yang disusun telah mampu digunakan untuk mengukur kualitas produk perangkat lunak atau belum.Ujicoba ini dilakukan dengan menyebarkan kuesioner kepada responden dosen dan mahasiswa (masing-masing 5 dosen dan 5 mahasiswa).

\subsection{UJI VALIDITAS}

Pada penelitian ini menggunakan uji validitas dan reliabilitas dengan menggunakan aplikasi SPSS. Uji validitas ini dilakukan untuk melihat nilai signifikan dari masing-masing instrument yaitu 26 item instrumen kuesioner untuk dosen dan 26 item kuesioner untuk mahasiswa dengan responden dari 5 orang dosen dan 5 orang mahasiswa.

Hasil dari pengujian reliabilitas menunjukkan bahwa semua data yang digunakan dalam penelitian ini memiliki nilai Alpha Cronbach > 0.6, maka dapat diambil kesimpulan semua data yang digunakan dalam penelitian ini dapat dipercaya / reliabel.

\subsection{UJI COBA}

Ujicoba dilakukan dengan menggunakan data set berupa data kuesioner untuk menilai kualitas sistem informasi di dua perguruan tinggi yaitu di Institut Teknologi Sepuluh Nopember Surabaya dan di Universitas Borneo Tarakan. Kuesioner berisi pernyataan-pernyataan yang akan digunakan untuk mendapatkan nilai masing-masing subkarakteristik. Peneliti menyebarkan 40 kuesioner kepada dosen dan mahasiswa(30 mahasiswa dan 10 dosen) untuk tiap perguruan tinggi.

\subsection{HASIL PENELITIAN}

Penelitian ini menggunakan dua responden yaitu dosen dan mahasiswa, sedangkan yang dijadikan objek dari penelitian ini adalah Sistem informasi akademik Modul FRS online yang digunakan digunakan di Institut Teknologi Sepuluh Nopember Surabaya dan Universitas Borneo Tarakan.Data dari kuesioner inilah kemudian diolah berdasarkan masingmasing responden.

\subsection{EVALUASI DAN PEMBAHASAN}

Evaluasi model yang diusulkan akan dievaluasi menggunakan Metrics Evaluation Method (Bekhamal dkk, 2009). Metode evaluasi ini memungkinkan pemahaman yang lebih baik dalam mengevaluasi produk perangkat lunak.

Tabel 4.1 Perbedaan Penilaian Responden Menggunakan Model Lama

\begin{tabular}{|l|c|c|c|}
\hline Siakad & Dosen & Mahasiswa & Perbedaan \\
\hline Siakad ITS & 77.48 & 84.50 & 7.02 \\
\hline Siakad Borneo & 79.43 & 80.61 & 1.18 \\
\hline \multicolumn{3}{|c|}{ Rata-rata Perbedaan } & 5.84 \\
\hline
\end{tabular}

Tabel 4.2 Perbedaan Penilaian Responden Menggunakan Model Baru

\begin{tabular}{|l|c|c|c|}
\hline Siakad & Dosen & Mahasiswa & Perbedaan \\
\hline Siakad ITS & 76.11 & 84.44 & 8.33 \\
\hline Siakad Borneo & 80.61 & 86 & 7.23 \\
\hline \multicolumn{3}{|c|}{ Rata-rata Perbedaan } & 1.1 \\
\hline
\end{tabular}


Hasil penelitian menunjukkan bahwa ratarata perbedaan penilaian kualitas sistem informasi akademik modul FRS online yang dilakukan menggunakan model lama yaitu sebesar 5.44. Hasil penelitian menunjukkan bahwa rata-rata perbedaan penilaian kualitas Sistem informasi akademik modul FRS online yang dilakukan menggunakan model baru yaitu sebesar 4.74 .

Proses selanjutnya yaitu menghitung perbedaan nilai kualitas sistem informasi akademik modul frs online menggunakan model baru berbobot (model yang diusulkan). Perbedaan penilaian responden dengan menggunakan model baru berbobot dapat dilihat pada tabel berikut. Tabel 4.3 Perbedaan Penilaian Responden Menggunakan Model Baru Berbobot

\begin{tabular}{|l|l|c|c|}
\hline Siakad & Dosen & Mahasiswa & Perbedaan \\
\hline Siakad ITS & 82.79 & 75.54 & 7.25 \\
\hline Siakad Borneo & 85.56 & 84.87 & 3.77 \\
\hline \multicolumn{2}{|c|}{ Rata-rata Perbedaan } & 3.48 \\
\hline
\end{tabular}

Hasil penelitian menunjukkan bahwa model lama menghasilkan rata-rata perbedaan sebesar 5.84.Model baru menghasilkan rata-rata perbedaan 1.1. Model yang diusulkan(model baru berbobot)menghasilkan rata-rata perbedaan 3.48 sehingga dapat disimpulkan bahwa model yang dihasilkan dalam penelitian ini lebih akurat sebesar 2.36 daripada model lama.

Hasil penelitian ini menunjukkan bahwa model yang diusulkan lebih akurat dibandingkan model lama, karena :

1. Penambahan dua subkarakteristik pada ISO 25010 karakteristik operabilitas yaitu helpfullness dan technical accessibility, mampu menaikkan akurasi model baru.

2. Adanya perbedaan bobot antara penilaian kualitas dari responden pakar, menunjukkan bahwa bobot kualitas model yang berbeda sesuai dengan responden membuat model penilaian kualitas menjadi lebih akurat. Responden mempunyai kebutuhan dan harapan yang berbeda terhadap sistem informasi akademik modul frs online.

3. Hasil pengukuran dari penelitian ini sudah memenuhi standar pengukuran kualitas. Standar kualitas untuk suatu aplikasi web adalah 70(Hidayati dkk, 2009), maka Sistem informasi akademik sudahmemenuhi standar pengukuran kualitas dari responden dosen dan mahasiswa.

\section{Kesimpulan}

Penelitian ini melakukan penyusunan dan pengujian metrik operabilitas untuk sistem informasi akademik berdasarkan ISO 25010.Diharapkan hasil yang didapatkan dari penelitian ini dapat menjadi masukan yang memperkaya kajian literatur dan empiris terkait pengukuran kualitas perangkat lunak menggunakan ISO/IEC 25010.Secara lebih spesifik, diharapkan dapat terbentuk sebuah metrik pengukuran atas kualitas Sistem Informasi yang dapat diterapkan secara umum berdasarkan ISO/IEC 25010 karakteristik operabilitas. Berdasarkan pembahasan hasil penelitian dapat disimpulkan bahwa :

1. Data yang dibutuhkan untuk melakukan penyusunan dan pengujian metrik operabilitas untuk sistem informasi akademik berdasarkan ISO 25010 diperoleh dari studi literatur, wawancara serta penyebaran kuesioner kepada responden pakar, dosen dan mahasiswa. Hasil dari uji validitas dan reliabilitas menunjukkan bahwa semua data yang digunakan telah valid dan reliabel.

2. Model kualitas yang diusulkan lebih akurat sebesar 2.36 daripada model kualitas yang lama dalam menilai kualitas sistem informasi akademik modul frs online. Peningkatan ini disebabkan oleh adanyapenambahan

subkarakteristik baru yaitu helpfulness dan Technical 
accessibility.Serta adanya perbedaan bobot antara penilaian kualitas dari pakar.

3. Pembobotan model kualitas sistem informasi akademik yang dilakukan menggunakan metode Analytical Hierarchy Process (AHP) menghasilkan bobot faktor kualitas yang bersifat hirarki dan konsisten, data diperoleh dengan menyebarkan kuesioner yang diisi oleh pakar yang ahli dalam bidang manajemen kualitas perangkat lunak.

4. Hasil pengukuran dari penelitian ini sudah memenuhi standart pengukuran kualitas perangkat lunak.

\section{DAFTAR PUSTAKA}

[1] Al-Safadi, L.A., dan Garcia, R.A., (2012), "ISO 9126 Based Quality Model forEvaluating B2C eCommerce Applications - A Saudi Market Perspective", IJCIT, Volume 03, Issue 02.Azuma, M. (2008).ISO/IEC CD 25010. Shinjuku: Departement Of Industrial Eng. AndManagement Systems Eng. Waseda University.

[2] Azuma, M., Komiyama, T., \& Yamashita, H. (2011). Investigate Report On Measure ForSystem/Perangkat lunak Product Quality Requirement Definition And Evaluation. Japan:Ministry Of Economy, Trade And Industry.

[3] Behkamal, B., Kahani, M., dan Akbari, M.K., (2009), "Customizing ISO 9126 quality model for evaluation of $B 2 B$ applications", Information and Software Technology, 51, pp. 599609.

[4] Hidayati, A., Sarwosri, dan Ririd,

A.R.T.H, (2009), “Analisa

Pengembangan Model

Kualitas Berstruktur Hirarki
Dengan Kustomisasi ISO 9126

Untuk Evaluasi

Aplikasi Perangkat Lunak B2B",

Tesis, Program Studi Teknik

Informatika, Institut Teknologi

Sepuluh Nopember.

[5] Membrate, T., W., (2010), “A

Framework For Evaluating Academic Website's Quality From Students "Persfective", Thesis, Department Of Software Tecnology Faculty EEMCS, Delft University of technology, Netherlands.

[6] Sugiyanto, (2015). Buku Tesis Perbaikan Model Penilaian Kualitas Perangkat Lunak Pada Domain Situs Web Perguruan tinggi Berbasis Pendekatan Multi Perspektif.

[7] Wagner, S. (2013). Perangkat lunak Product Quality Control. New York: Springer-Verlag Berlin Heidelberg.

[8] Wagner, S. (2013). Perangkat lunak Product Quality Control. New York: Springer-Verlag Berlin Heidelberg. 